Jolanta Gładys-Jakóbik

\title{
KOBIETY W PRZESTRZENI PUBLICZNEJ
}

\section{Definicje przestrzeni prywatnej i publicznej}

W ciągu ostatnich dwudziestu lat w polskiej przestrzeni publicznej zaobserwowano wiele zmian, które odnoszą się także do kategorii kobiet. Zmieniająca się rzeczywistość społeczna i ekonomiczna zmusza bowiem do stawiania pytań o motywy ich uczestnictwa $\mathrm{w}$ działaniach publicznych, analizy stosowanych przez nie strategii działania czy też trwałości dotychczasowych modeli. ${ }^{1}$

Przestrzeń publiczna staje się coraz bardziej zróżnicowana, co dodatkowo komplikuje sposoby jej definiowania. A społeczeństwo polskie, mające za sobą wieloletnie doświadczenie związane $\mathrm{z}$ funkcjonowaniem w gospodarce socjalistycznej, wydaje się być mocno wyczulone na kwestię jednoznacznego określenia zakresu podmiotowości sfery publicznej, a przede wszystkim - zasad, które pozwalają na jej oddzielenie od przestrzeni prywatnej.

Warto zatem zdefiniować samo pojęcie „przestrzeni publicznej”, określić kategorie, za pomocą których są wyznaczane jej granice, czy wreszcie pokazać, kto i co na nią wpływa i kim są działające na niej podmioty.

Potoczne pojmowanie „przestrzeni publicznej” wiąże się z uznawaniem jej za taki rodzaj strefy fizycznej, która jest dostępna dla każdej jednostki czy zbiorowości, bez konieczności spełnienia jakichś dodatkowych, zewnętrznie narzuconych warunków. Byłaby to zatem przestrzeń wspólna, w ramach której dochodzi do interakcji społecznych związanych z koniecznością zaspokajania różnorodnych potrzeb, uwzględniających obowiązujące w danym społeczeństwie systemy wartości. W tym kontekście przestrzeń publiczna byłaby także przestrzenią społeczną, istniejącą zawsze w ramach jakiegoś porządku ontologiczno-aksjologicznego, dzięki któremu da się wyraźnie wyznaczyć jej granice czy też określić kompetencje działających w jej ramach aktorów. Tak rozumiana przestrzeń stanowiłaby zatem efekt zarówno pracy zbiorowości, jak i oddziaływań jednostkowych. ${ }^{2}$

\footnotetext{
1 J. Kowalczyk, Paradygmat zmian w przestrzeni publicznej kobiet, Teka Kom. Politol. i Stosunków Międzynarodowych - OL PAN, Warszawa 2009, s. 4, 18-28.

2 Por. J. Habermas, Strukturalne przeobrażenia sfery publicznej, Wydawnictwo Naukowe PWN, Warszawa 2007.
} 
Na gruncie nauk humanistycznych, szczególnie filozofii, socjologii czy politologii, podejmowane były próby pełniejszego zdefiniowania przestrzeni publicznej. W ramach najczęściej wykorzystywanej koncepcji liberalnej to, co prywatne, jest wyraźnie różne od tego, co publiczne. Według J.M. Milla sfera prywatna wiąże się z prawem jednostki do działania, jej wolnością i wyznaczaną przez nią przestrzenią, pozwalającą na realizację tej wolności. Sfera publiczna natomiast oznacza działania innych, prawnie określone, uporządkowane, uzgodnione, umożliwiające sprawne praktykowanie życia społecznego, w ramach którego jednostki wiedzą, jak się zachować i działać, a zbiorowości uznają konieczność poddania się zaakceptowanym regułom, których konsekwencją jest utrata części swobody, ale jednocześnie uzyskanie bezpieczeństwa i trwałości w ramach wcześniej uzgodnionego porządku. ${ }^{3}$

We współczesnych teoriach neoliberalnych, włącznie $\mathrm{z}$ najbardziej znaną, J. Rawlsa, także mamy do czynienia z rozróżnieniem obu tych sfer. Do prywatnej zalicza on poglądy jednostki z zakresu religii i filozofii, wyznawane przez nią normy etyczne, poglądy dotyczące dobra wspólnego czy też konstrukcje pozwalające na indywidualne budowanie pewnej społecznej wizji działania lub funkcjonowania jej samej, a także wcielanie jej w życie pod postacią zgody na określone formy obyczajowości.

Publiczne natomiast jest wszystko to, co wiąże się z powstałym w wyniku umowy społecznej państwem, co przybiera kształt politycznych działań i jest prawnie określone, ze szczególnym uwzględnieniem zasady sprawiedliwości. W koncepcji Rawlsa granice przestrzeni prywatnej i publicznej są wyraźnie wydzielone. Co ciekawe, autor ten zwraca uwagę, że wolność jednostki może także przybrać charakter destrukcyjny, stąd jego zgoda na przejawy interwencjonizmu państwowego i ograniczanie praw jednostki, których celem jest bardziej racjonalne kształtowanie działań publicznych. Warto zaznaczyć, że odbywa się to jednak zawsze przy zachowaniu dyskursu publicznego, umożliwiającego budowanie społecznego konsensusu i ograniczanie możliwości marginalizacji jednostki, a więc tego, co określa on mianem „szkodliwości dla innych". ${ }^{4}$

W omawianej koncepcji pojawia się postulat neutralności sfery publicznej, mający na celu ograniczenie możliwości zawłaszczenia choćby części wolności indywidualnej, co byłoby możliwe, gdyby doszły do głosu partykularne interesy lub gdy w sytuacji pozorowanej demokratyzacji życia społecznego, ujawni się możliwość budowania „jedynie słusznego" modelu rzeczywistości. Rawls przypomina, że przestrzeń publiczna powinna być konstruowana w oparciu o wartości uniwersalne,

\footnotetext{
3 Por. J.S. Mill, O wolności, Akme, Warszawa 1999, cyt. za: I. Kowalczyk, op.cit., s. 19.

${ }^{4}$ J. Rawls, Liberalizm polityczny, Wydawnictwo Naukowe PWN, Warszawa 1998.
} 
takie jak: wolność, równość wobec prawa, sprawiedliwość, jakość życia, pluralizm i neutralność światopoglądowa. Jego zdaniem pozwoli to na takie funkcjonowanie tej przestrzeni, w której egoistyczne, chociaż zasadne moralnie, religijnie czy filozoficznie postawy jednostek jej nie zaburzą i nie doprowadzą do dysfunkcji poprzez generowanie napięć, konfliktów czy też - w skrajnej postaci - zaakceptowania wojny jako formy uzasadnionego działania. ${ }^{5}$

Interesujące stanowisko dotyczące przestrzeni prywatnej i publicznej na gruncie socjologii znajdziemy u D. Helda. Według niego przestrzeń publiczna to miejsce, gdzie ,jednostki powinny mieć zapewnioną wolność i równość wyboru warunków własnego życia; oznacza to, że powinny mieć różne prawa (i odpowiednio różne obowiązki) w ustalaniu warunków stwarzających i ograniczających ich możliwości, o ile te warunki nie są tworzone kosztem praw innych ludzi”. ${ }^{6}$

W tym rozumieniu konstrukcja sfery publicznej opierałaby się na zasadach autonomii, autorefleksji i samostanowienia, co pozwala stworzyć rozwiązania społeczne, które uwzględniałyby takie przesłanki, jak:

1) określenie warunków, dzięki którym każdy uzyskałby prawo do samokształcenia i rozwijania swoich uzdolnień;

2) ograniczenie autorytaryzmu władzy politycznej i jej prawa do stosowania przymusu poprzez wypracowanie metod, które pozwalają na uzyskanie zgody obywateli co do zasad rządzenia, szczególnie w przypadku, gdy decyzję podejmuje mniejszość w imieniu większości;

3) inicjowanie i rozbudowa procesów opiniotwórczych, pozwalających na tworzenie struktur budowanych na zasadzie współistnienia;

4) poszerzanie ekonomicznych możliwości dostępnych zasobów - zakładające, że jednostki są w najlepszej pozycji, by osiągać swe cele wówczas, gdy zaspokajanie potrzeb materialnych nie jest zbyt absorbujące. ${ }^{7}$

Spełniając te przesłanki, konstruuje się przestrzeń publiczną, w której obywatele są świadomi swych praw i obowiązków, aktywni politycznie i społecznie, zaangażowani nie tylko w realizację partykularnych interesów, ale także w działania umożliwiające dostrzeżenie potrzeb i dążeń innych tak, by każdy „głos został usłyszany”.

Zasada autonomii powinna obowiązywać także w przestrzeni prywatnej. Zdaniem Giddensa rozbudowywanie demokracji stwarza nowe szanse dla tworzenia i organizowania przestrzeni prywatnej. Czyste relacje w sferze seksualnej,

5 J. Rawls, Teoria sprawiedliwości, Wydawnictwo Naukowe PWN, Warszawa 1994.

6 D. Held, Models of Democracy, Polity Press, Cambridge 1986, za: A. Giddens, Przemiany intymności. Seksualność, miłość i erotyzm we współczesnych społeczeństwach, Wydawnictwo Naukowe PWN, Warszawa 2007, s. 219.

7 Ibidem, s. 218.

8 Ibidem, s. 220. 
rodzicielskiej czy przyjacielskiej pozwalają bowiem „na skuteczną realizację refleksyjnego projektu tożsamości osobistej, która jest warunkiem współistnienia z innymi na równych zasadach; [...] wymaga autonomicznego stosunku do przeszłości, od którego z kolei zależy kolonizacja przyszłości. Tak rozumiana autonomia jednostki pozwala zachować szacunek dla potencjału innych ludzi - klucza porządku demokratycznego. Jednostka autonomiczna uważa innych za takich, jakimi są, i nie widzi w niezależnym rozwoju ich potencjału zagrożenia dla siebie".

Taki sposób definiowania przestrzeni prywatnej i publicznej oznacza jednak w praktyce konieczność redefiniowania ról społecznych, pozycji i dystansów, które przekomponowane lub zbudowane na nowo prowadzą do ponownego zdefiniowania struktury społecznej i konstruowania jej, ale już według nowych wzorów.

Warto w tym miejscu, za Seylą Benhabib, przedstawić rozumienie przestrzeni publicznej/prywatnej pojawiającej się w koncepcji Hannah Arendt. Pokazała ona sposób konstrukcji pojęcia przestrzeni publicznej, która opiera się na dwóch modelach: agonistycznym i asocjacyjnym. Pierwszy $z$ nich jest elitarny i trudno dostępny. Przestrzeń publiczna jawi się jako miejsce zmagań jednostek, których celem jest osiągnięcie jak najbardziej czytelnej pozycji, uznania i prestiżu. Dystanse międzyludzkie są w niej odległe, co oznacza, że więcej ludzi dzieli niż łączy. Taki rodzaj organizacji przestrzeni publicznej wymaga stosowania ostrych kryteriów przynależności, wymuszających lojalność uczestników nastawionych na indywidualną nagrodę, jaką jest zwycięstwo.

Drugi model, asocjacyjny, stanowi przeciwieństwo pierwszego. Opisuje wspólnie działających ludzi, nastawionych na współpracę i pomoc, dzięki którym zyskują oni możliwość stworzenia nowej społecznej jakości, opartej na konsensusie zarówno co do ustalonych wartości, jak i podejmowanych działań. ${ }^{10}$

Przestrzeń prywatną Arendt utożsamia ze sferą własności i rodziną. Stawia ostrą granicę pomiędzy ludzką egzystencją w wymiarze osobistym, jednostkowym, ukierunkowaną na zaspokajanie podstawowych potrzeb poprzez pracę i wytwarzanie. Sferą tą rządzi przymus biologiczny, konieczność działania także wspólnego, ale takiego, które charakteryzuje bardziej ograniczenie niż wolność. Wolność stanowi bowiem domenę przestrzeni publicznej. ${ }^{11}$

Zastosowanie takiego rozróżnienia pozwala Arendt definiować „narzędzia”, dzięki którym możliwe staje się w ogóle opisanie przestrzeni publicznej kobiet.

9 Ibidem, s. 222-223.

10 Por. S. Benhabib, Feministic Theory and Hannah Arendt's Koncept of Public Space, London 1993, za: W. Heller, Trudne porozumienie feminizmu z filozofia polityczna Hannah Arendt. Humanistyka i płeć. Publiczna przestrzeń kobiet: obrazy dawne i nowe, Wydawnictwo Naukowe UAM, Poznań 1999, s. 222-224.

11 Por. H. Arendt, Kondycja ludzka, Fundacja Aletheia, Warszawa 2000. 
Przykładem, który wydaje się dobrze ilustrować zmiany w postrzeganiu przestrzeni publicznej i prywatnej w Polsce w ostatnich latach, są badania J. Miluskiej, prowadzone jeszcze w połowie lat dziewięćdziesiątych XX wieku. Pokazywały one, że budowa systemu demokratycznego wpłynęła na pojawienie się tendencji sygnalizujących zmianę nastawienia kobiet i mężczyzn wobec tradycyjnie definiowanych ról, opartych na dychotomii: kobieta-matka, mężczyzna-ojciec, pracownik-obywatel.

Widoczne stało się szczególnie rozszerzenie kobiecych ról, które dodatkowo podkreśliły pojawienie się zmian o charakterze świadomościowym. Dzięki nim liczne grupy Polek przestały ograniczać swoje działania jedynie do przestrzeni prywatnej, domowej czy rodzinnej, coraz częściej zaczęły ubiegać się o miejsce w przestrzeni publicznej, zarezerwowanej do tej pory dla mężczyzn i zdominowanej przez wyznaczone przez nich reguły. ${ }^{12}$

Pierwsze działania kobiet związane z koniecznością redefiniowania obecności w przestrzeni publicznej były związane $z$ brakiem ich zgody na kontynuowanie negatywnych atrybutów, tradycyjnie przypisywanych kobietom, które pozwalały na dyskryminację i brak równości, przy jednoczesnych deklaracjach o jej braku na poziomie prawnym czy społecznym.

J. Miluska stwierdza, że przedłużanie tego stanu może prowadzić do pojawienia się zjawiska fałszywej tożsamości społecznej („typowości”), która oznacza, że zachowania kobiet stają się coraz bardziej zunifikowane. Utrudnia to rozwój nowego repertuaru cech i zachowań, które mogłyby gwarantować adaptację i satysfakcję w nowych warunkach społeczno-ekonomicznych Polski. ${ }^{13}$

Zmiana dotychczasowego paradygmatu zaczęła być szczególnie widoczna w ostatnich latach, głównie za sprawą rosnącego bezrobocia i konieczności przejęcia przez kobiety odpowiedzialności za byt rodziny. Wprawdzie struktura bezrobocia, analizowana pod względem płci, nadal ujawnia istnienie patriarchalnego paradygmatu, coraz częściej jednak to elastyczna postawa kobiety umożliwiała jej przejęcie dominującej pozycji w rodzinie, a często także poza nią.

Zmianom zakresu uczestnictwa w przestrzeni publicznej kobiet mogłyby sprzyjać także rozwiązania prawne i organizacyjne. Rozbudowywanie świadomości kobiet łączy się bowiem z możliwościami jej uzewnętrznienia w przestrzeni publicznej. Coraz częściej dostrzegają one realne korzyści (indywidualne czy zbiorowe), wynikające z rozszerzenia sfery prywatnej i częstszej, bardziej aktywnej obecności w społecznej przestrzeni publicznej.

12 J. Miluska, Przekształcenie ról płciowych a szanse kobiet. Humanistyka i płeć. Studia kobiece z psychologii, filozofii i historii, Wydawnictwo Naukowe UAM, Poznań 1995, s. 19-38.

13 Ibidem, s. 23. 
Już R. Dahl, pisząc o motywach działania ludzkiego, wskazywał na trzy typy interesów, które mogą wpływać na większą aktywność jednostek. Były to:

1) potrzeba maksymalizowania wolności człowieka, zawsze w kontekście realnych możliwości jej uzyskania i bez szkodzenia innym;

2) potrzeba samodoskonalenia, tj. inwestowania w siebie i swój potencjał;

3) potrzeba satysfakcji z podejmowanych działań, wynikająca z obiektywnej samooceny i uznania siebie za ważnie działający podmiot. ${ }^{14}$

Odnosząc tę kategoryzację do postaw kobiet, można stwierdzić, że tak sformułowane interesy mogą być istotnym bodźcem do zmiany nastawienia kobiet i wyboru przez nie nowych sposobów uczestnictwa w życiu społecznym.

Kobiety, a coraz częściej także ich otoczenie, wykształcają w sobie przekonanie, że zmiana aktywności nie musi dotyczyć wyłącznie tego, co prywatne i czego w wielu przypadkach nie widać, bo toczy się w domu, ale może rozszerzać się również na działania o charakterze społecznym, politycznym czy zawodowym. Dodatkowo przynosi ona taki sam poziom satysfakcji jak ta, która wynika z interakcji prywatnych na poziomie naturalnym. Tym samym może mobilizować przynajmniej część kobiet do śmielszego prezentowania własnych pragnień i podejmowania konkretnych działań.

Przyjmowane strategie przypominają najczęściej tę, którą się określa mianem „małych kroków”; pozwala ona jednak na zwiększenie obecności kobiet w administracji publicznej, polityce czy biznesie, i to nie tylko w roli pracowników szeregowych, ale często na stanowiskach o poszerzonym zakresie władzy i odpowiedzialności.

Istotnym powodem zachęcającym kobiety do działania jest poczucie satysfakcji z tego, co robią. Zjawisko to jest szczególnie widoczne na poziomie lokalnym, gdzie formułowanie celów działania ma bezpośrednie przełożenie na jasno sformułowane i konkretne potrzeby. Kobiety: sołtysi, wójtowie, radne i lokalne działaczki wychodzą poza rodzinę i jej oczekiwania, występując w imieniu zbiorowości. Pytane o motywy działania, odpowiadają, że problemy na szczeblu lokalnym są im bliższe, lepiej znane, bo wiążą się z konkretnymi ludźmi, z którymi czują więź i solidarność. Poza tym dostają od nich zachętę, rodzaj psychicznego wsparcia, co także stanowi o sile napędowej podejmowanych działań. Istotne jest również to, że do rozbudowanych interakcji w lokalnej przestrzeni publicznej dochodzi zwykle blisko miejsca zamieszkania, co tym samym pozwala im na łączenie tradycyjnej roli matki i działaczki społecznej. ${ }^{15}$

Współczesne realia życia społecznego nie pozwalają jeszcze na dokonanie jednoznacznej oceny obecności kobiet w przestrzeni publicznej. Wielu badaczy uważa na

4 R. Dahl, Demokracja i jej krytycy, Znak, Warszawa 1995, s. 127.

15 Badania na ten temat prowadził zespół pod kierunkiem R. Siemieńskiej. O rezultatach możemy przeczytać w pracy: Płeć. Wybory. Demokracja, red. R. Siemieńska, IFiS PAN, Warszawa 2005. 
przykład, że ich nastawienie do działania, przełożenie na konkretne formy i wymiary aktywności ciągle pozostawiają wiele do życzenia. A dostępne dane, odnoszące się do takich zagadnień, jak: kobiety w służbie publicznej, kobiety w mediach czy kobiety w nauce i biznesie, pokazują bardzo niejednorodny obraz zjawiska.

$\mathrm{W}$ oficjalnych wystąpieniach podkreśla się rosnącą rolę kobiet $\mathrm{w}$ przestrzeni publicznej. Było to szczególnie widoczne w okresie poprzedzającym polską prezydencję w UE. Irena Lipowicz, Rzecznik Praw Obywatelskich, zaproponowała nawet, aby kwestia udziału polskich kobiet w przestrzeni publicznej, stała się jej wyróżniającą cechą ${ }^{16} \mathrm{O}$ tym, że jest to ważny problem, świadczą dostępne dane liczbowe. Pokazują one m.in., że kobiety w środowisku akademickim stanowią dzisiaj $65 \%$ absolwentów, $44 \%$ doktorów, $18 \%$ profesorów zwyczajnych i $7 \%$ zarządzających nauką. Co warto podkreślić, to to, że aż $65 \%$ stypendiów naukowych otrzymują mężczyźni. ${ }^{17}$

A zatem, mimo że zwiększa się procentowy udział kobiet w nauce (warto przy okazji spytać, jakich dziedzin dotyczy), to nadal większy dostęp do aktualnej wiedzy mają mężczyźni. Bo nie sądzę, aby przywoływane informacje oznaczały większe zdolności i kompetencje mężczyzn w porównaniu z kobietami. Co więcej, większość stypendiów przypada na nauki ścisłe, będące niejako „od zawsze” domeną mężczyzn. Sprawa jest więc bardziej złożona, niż sugerowałyby to przywoływane w tym miejscu dane liczbowe.

Wskazuje to raczej na istniejący nadal stereotypowy podział obowiązków w rodzinie; swoiste „uwiązanie” kobiet w domu, które ma wynikać z ich niejako „naturalnych” predyspozycji. W tym względzie istotną kwestią jest np. liczba żłobków i przedszkoli. Niewątpliwie ich większa liczba, łatwiejszy dostęp i praca dostosowana do godzin pracy rodziców pozwoliłyby kobietom na godzenie wielu, czasami sprzecznych ról. Nie ma bowiem co ukrywać, że to na kobietach nadal spoczywa obowiązek zajmowania się dziećmi i konieczności ograniczania pracy zawodowej na rzecz obowiązków rodzicielskich.

W trakcie prowadzonej na spotkaniu z I. Filipowicz dyskusji pojawiły się dwie istotne informacje, mające znaczenie dla wyjaśnienia sytuacji kobiet $\mathrm{w}$ sferze publicznej. Jak podkreślali dyskutanci, przeszkodą na drodze do ich sukcesu jest, po pierwsze, brak sieci kontaktów, które ułatwiałyby im promocję na wyższe stanowiska, i po drugie - aby osiągnąć sukces, kobiety muszą nauczyć się bardziej cenić sobie władzę niż dobre relacje międzyludzkie. Czy jest to możliwe i czy jest to konieczne?

Obie kwestie wymagają czasu i zmiany dotychczasowej świadomości na temat tego, co jest postrzegane jako „kobiece” lub „męskie”. W jakim paradygmacie

16 Kobiety w służbie publicznej - szklany sufit, http://www. Femka.net/kobiety-w-służbie-publicznejszklany sufit/ (dostęp 18.07.2010).

17 Ibidem. 
rzeczywistości społecznej, patriarchalnej, matriarchalnej, a może innym, mamy funkcjonować? Pytanie zasadnicze brzmi: Czy jedyną drogą do zapełnienia przestrzeni publicznej kobietami jest przyjęcie „męskiego", w stereotypowym ujęciu, punktu widzenia rzeczywistości? Kobiety powoli bowiem tę przestrzeń zapełniają i należy się zastanowić nad tym, czy dysponują odpowiednimi kompetencjami (społecznymi), aby się w niej odnaleźć.

Jak widać na rysunku 1, w 2009 roku w służbie cywilnej zatrudnionych było około 123 tys. osób. Kobiety stanowiły 69,2\% wszystkich zatrudnionych. Jedynie w placówkach zagranicznych zatrudnionych było mniej kobiet niż mężczyzn. W pozostałych urzędach zatrudnienie kobiet było większe od zatrudnienia mężczyzn i wahało się od $14 \%$ do $55 \%$. Ponadto największy udział zatrudnionych kobiet odnotowano w urzędach skarbowych $(77,3 \%)$, izbach skarbowych $(74,3 \%)$ i urzędach wojewódzkich (72,1\%), czyli w miejscach, które charakteryzuje mniejszy zakres władzy i niższy prestiż społeczny. Mniejszy odsetek kobiet zatrudnionych w placówkach zagranicznych wydaje się dobrze ilustrować zjawisko swoistego „wykluczenia” kobiet z dziedzin, które cieszą się większym poważaniem społecznym i wyższymi dochodami.

Rysunek 1. Zatrudnienie według płci w podziale na grupy urzędów w korpusie służby cywilnej (stan na dzień 31 grudnia 2009 roku, w \%)

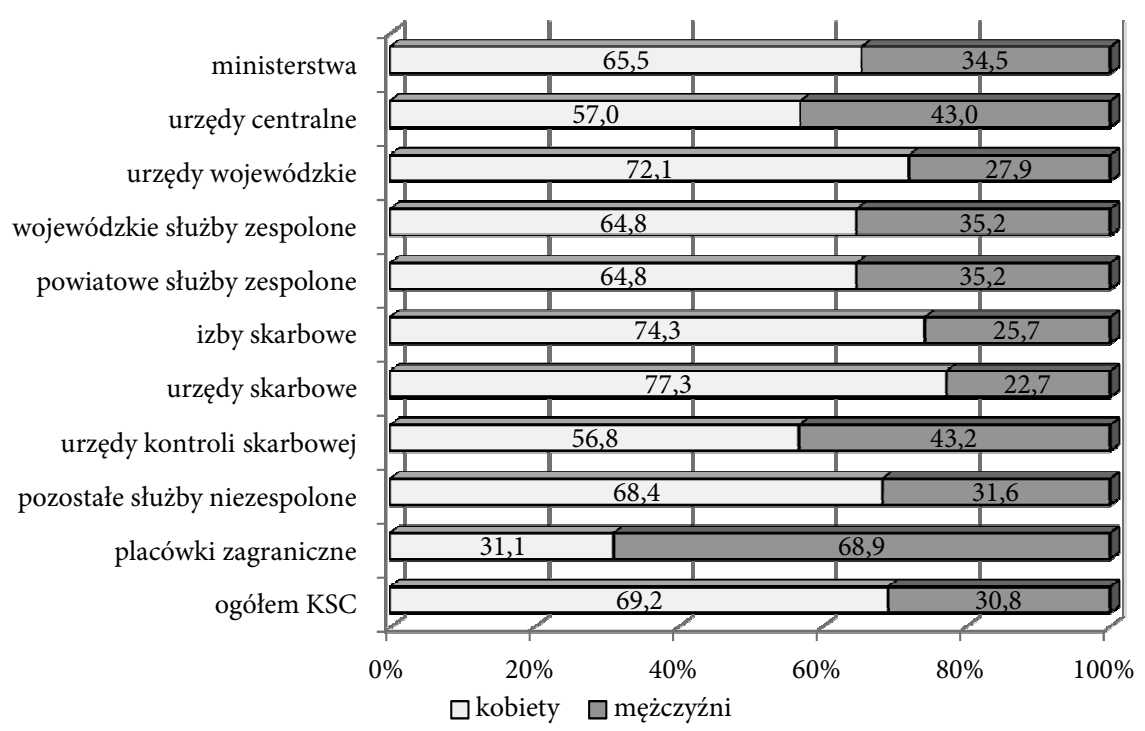

Źródło: www.dsc.kpm.gov.pl/userfiles/kobiety_w_sluzbie_publicznej.doc, w: www.Femka.net/kobiety-w-służbie-publicznej-szklanysufit/ (dostęp 18.07.2011). 
Kolejne rysunki zdają się potwierdzać wcześniejsze obserwacje, zaś uaktualnione dane z 31 grudnia 2010 roku pokazują, że w korpusie służby cywilnej zatrudnionych było $69,9 \%$ kobiet. W dalszym ciągu w placówkach zagranicznych zatrudnionych było mniej kobiet niż mężczyzn. W niewielkim zakresie uległ zmianie procentowy udział kobiet w zatrudnieniu w poszczególnych grupach urzędów. Największy udział zatrudnionych kobiet odnotowano w urzędach skarbowych $(77,6 \%)$, powiatowej administracji zespolonej (75\%), izbach skarbowych $(74,8 \%)$ i urzędach wojewódzkich $(72,4 \%)$. Natomiast na wyższych stanowiskach w służbie cywilnej zatrudnionych było 49,9\% kobiet.

Rysunek 2. Zatrudnienie według płci na wyższych stanowiskach w służbie cywilnej w podziale na grupy urzędów (stan na dzień 31 grudnia 2009 roku)

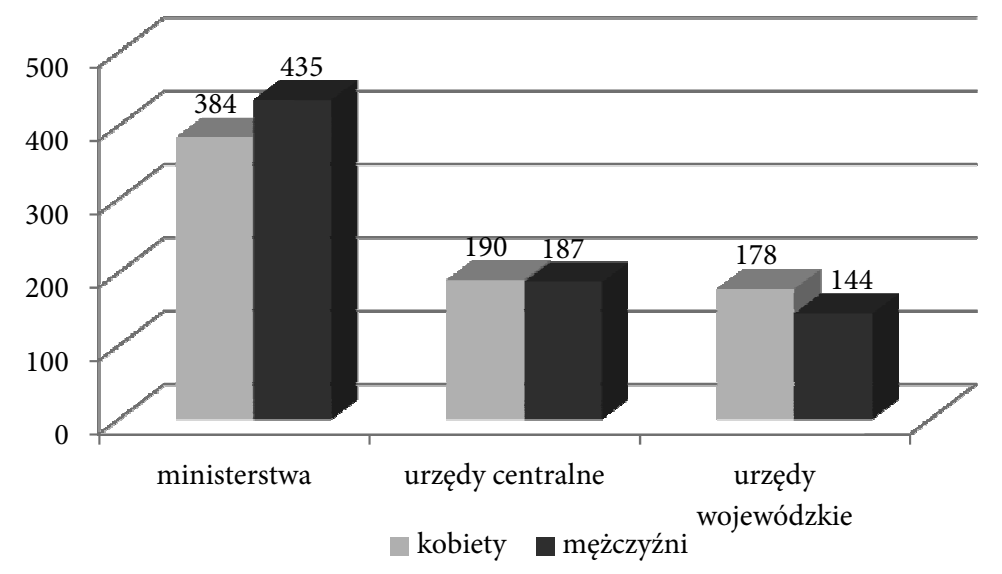

Źródło: www.dsc.kpm.gov.pl/userfiles/kobiety_w_sluzbie_publicznej.doc

Z około 1600 obsadzonych wyższych stanowisk w służbie cywilnej 50,6\% stanowią kobiety. W podziale na grupy urzędów rozkład kształtował się następująco: w ministerstwach - 46,88\%, w urzędach centralnych - 50,39\%, a w urzędach wojewódzkich - 55,28\%. Natomiast na najwyższym stanowisku w służbie cywilnej (dyrektora generalnego) zatrudnionych było $42 \%$ kobiet na 57 obsadzonych stanowisk.

Opierając się na danych uzyskanych z OECD, można zaobserwować zachodzące zmiany w odsetkach zatrudnionych kobiet $\mathrm{w}$ administracjach centralnych na przestrzeni ostatnich 10 lat (porównywano lata 1995 i 2005). Jak widać, we wszystkich krajach biorących udział w badaniu wystąpił wzrost zatrudnienia kobiet. Największy odnotowano w Polsce - o 18\%, następnie w Korei - o 10\% i Szwajcarii - o 9\% (zob. rysunek 4). 
Rysunek 3. Zatrudnienie pracowników kobiet $w$ administracjach centralnych

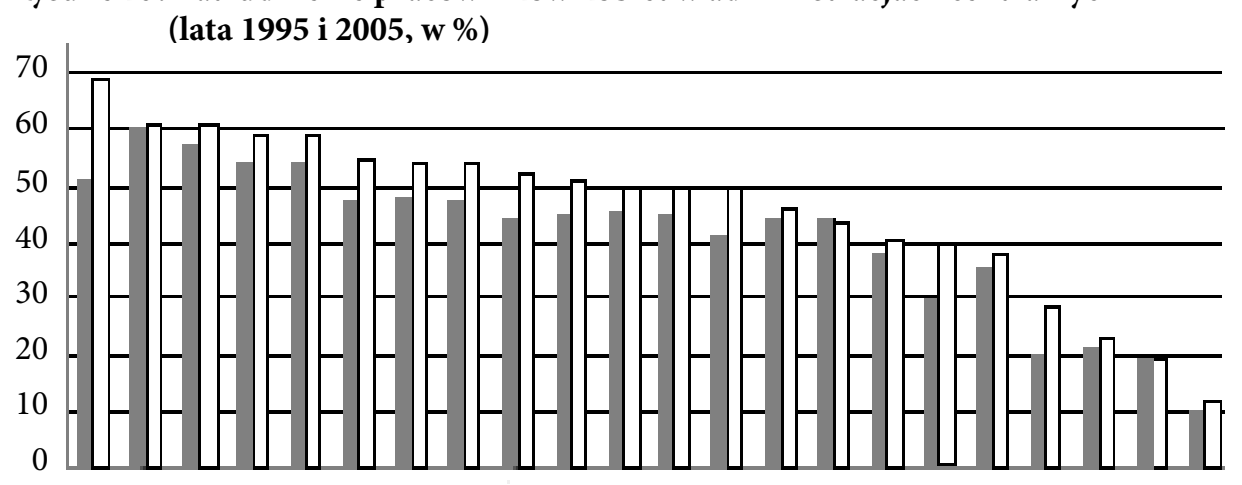

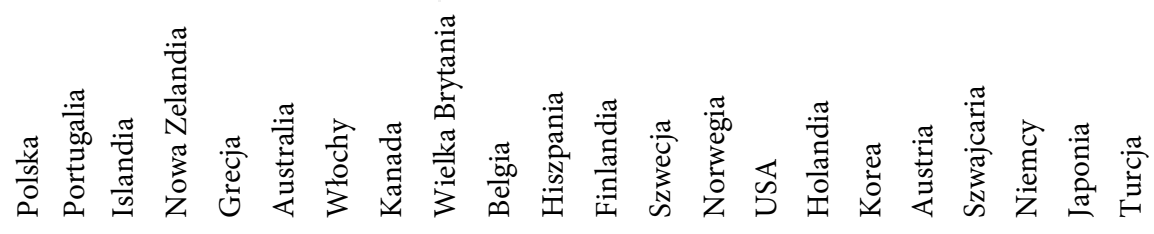

1995

2005

Źródło: www.dsc.kpm.gov.pl/userfiles/kobiety_w_sluzbie_publicznej.doc

Rysunek 4. Zatrudnienie pracowników kobiet $w$ administracjach centralnych w porównaniu $z$ ogółem zatrudnionych

(dane za 2005 rok, z Francji i Polski za 2004 rok, w \%)

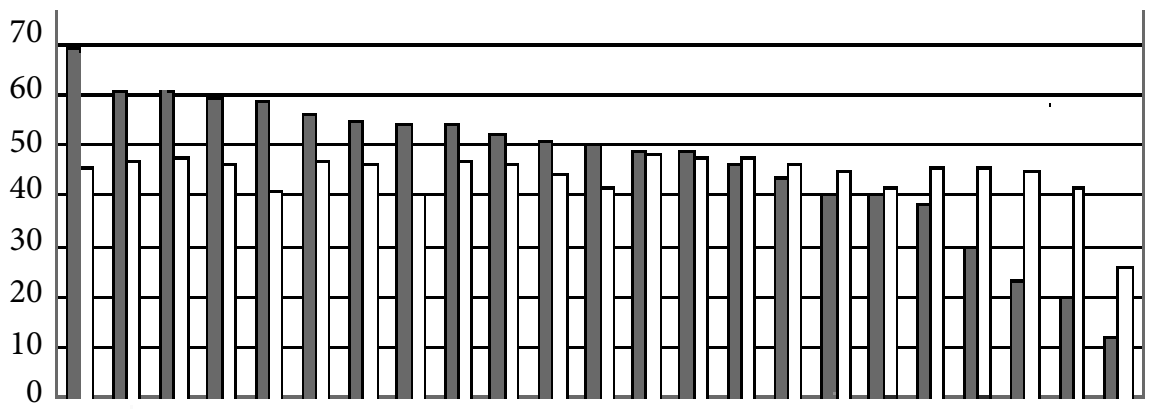

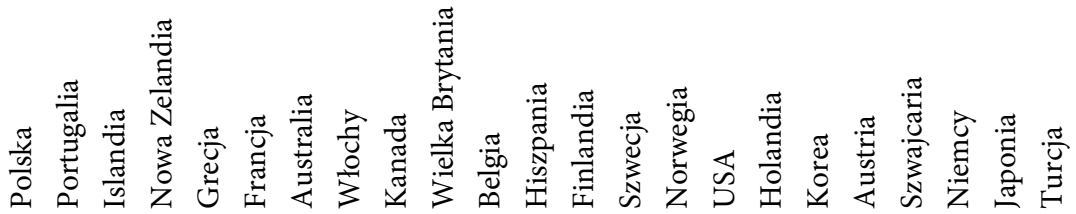

$$
\begin{aligned}
& \text { administracja rządowa } \square \text { ogół zatrudnionych }
\end{aligned}
$$

Źródło: www.dsc.kpm.gov.pl/userfiles/kobiety_w_sluzbie_publicznej.doc 
Największy udział kobiet zatrudnionych w administracji centralnej, spośród państw objętych badaniem, odnotowano w Polsce $-69 \%$, następnie w Portugalii i Islandii - 61\%, Nowej Zelandii i Grecji - 59\%. Najmniejszy zaś w Turcji - 12\%, Japonii - 20\% i Niemczech - 22\%. Z kolei największy udział kobiet zatrudnionych ogółem odnotowano w Finlandii i Szwecji - po 59\%, w USA, Norwegii i Szwajcarii - po 58\%, najmniejszy zaś w Turcji - 27\%, we Włoszech i Grecji - $41 \%$.

Z zaprezentowanych danych wynikałoby, że administracja rządowa to przyjazna kobietom sfera aktywności zawodowej. Przyczyn przewagi liczebnej kobiet w służbie cywilnej należałoby szukać w postrzeganiu tej instytucji jako pracodawcy, który daje gwarancję stabilności zatrudnienia, pozwala godzić życie zawodowe z życiem prywatnym, co dla wielu kobiet ma decydujące znaczenie. Ponadto obowiązujące przepisy prawne regulujące zasady funkcjonowania służby cywilnej są respektowane i zawierają jasne reguły postępowania zarówno dla pracowników, jak i pracodawców. W sytuacji niestabilnego rynku pracy jest to istotny atut.

$\mathrm{W}$ trakcie wspomnianego spotkania $\mathrm{z}$ I. Filipowicz zwracano uwagę na pojawianie się wielu negatywnych zjawisk, które odnoszą się do zatrudnienia kobiet zarówno w sektorze publicznym, jak i prywatnym. Podkreślano, że kobiety powinny bardziej się cenić. Tymczasem, jak wynika $\mathrm{z}$ wielu badań, mają one zazwyczaj niższe wymagania dotyczące wynagrodzeń. Okazuje się także, że na przestrzeni ostatnich lat różnice w wynagrodzeniach na tych samych stanowiskach pracy ulegają zwiększeniu na niekorzyść kobiet. Zaobserwowano także zjawisko zwiększonej przedsiębiorczości kobiet, którą tłumaczy się chęcią ucieczki przed dyskryminacją czy szklanym sufitem.

Warto zaznaczyć, że zaobserwowany wzrost odsetka kobiet zatrudnionych na wyższych stanowiskach być może należałoby wiązać z odpływem mężczyzn do lepiej płatnych zajęć niż z awansem kobiet. Nadal istotnym problemem są bowiem istniejące role i stereotypy; wiele kobiet na wyższych stanowiskach to osoby samotne.

Awansowi kobiet nie sprzyjają także trudności związane ze sposobami godzenia życia zawodowego z życiem prywatnym (rodzina, małe dzieci, starsi rodzice wymagający opieki).

W trakcie wspomnianego spotkania większość dyskutantów podkreślała, że o byciu dobrym i docenianym pracownikiem nie powinna decydować płeć, a wiedza i umiejętności, kompetencje oraz cechy osobowe, czyli to, co reprezentuje sobą konkretna jednostka. Aby to osiągnąć, konieczna jest jednak zmiana mentalności mężczyzn (i kobiet) poprzez organizowanie chociażby większej liczby szkoleń z tematyki dotyczącej równych szans. Elementem służącym zmianie świadomości społecznej niejako „z definicji” powinny być także media.

Czy tak jednak jest? Zobaczmy zatem, w jaki sposób kreowana jest przestrzeń publiczna w polskich środkach masowego przekazu. 


\section{Kształtowanie przestrzeni publicznej w mediach masowych}

Już J. Habermas pisał, że sfera publiczna jest taką dziedziną ludzkiej aktywności, w której formuje się opinia publiczna. Stanowi ona obszar, w którym ludzie mogą w wolny i niekrępujący sposób dyskutować na ważne dla siebie tematy i wywierać wpływ na działania polityków. W tym znaczeniu sfera publiczna znajdowałaby się pomiędzy sferą prywatną a sferą związaną z władzą.

Można ją zatem potraktować jako, z jednej strony, ważną instytucję monitorowania działań władzy, $\mathrm{z}$ drugiej zaś obszar, w którym jednostki zbierają się po to, by przedyskutować istotne dla siebie problemy. Sfera ta stanowi jeden z fundamentów demokracji, ponieważ, jak się zakłada, jedynie władza, która odwołuje się do opinii publicznej, może być traktowana jako w pełni demokratyczna. Wolne media we współczesnym świecie powinny zatem być wyrazicielem opinii publicznej i miejscem prowadzenia dyskursu.

Tymczasem interes ekonomiczny i dążenie do niczym nieograniczonej wolności przyczyniły się do niekoniecznie pozytywnych zmian. Prasa, radio, telewizja z medium „społecznego" ewoluowały w stronę medium "reklamowego". A po uzyskaniu silnej pozycji stały się praktycznie monopolistami w zakresie dystrybucji informacji.

B. Grabowska opisuje to zjawisko, posługując się terminem refeudalizacji, ${ }^{18}$ oznaczającym rządy mediów pozbawionych kontroli społecznej.

Tymczasem przywoływany wcześniej J. Habermas pisał, że wolna prasa nie może być traktowana jak każde inne dobro konsumpcyjne, a informacje nie mogą być sprzedawane jak towary. Obserwując rozwój wydarzeń nie tylko w Polsce, ale również w innych krajach, można jednak odnieść wrażenie, że są to postulaty w dużej mierze niezrealizowane. Przykładem mogą być prowadzone dyskusje na tematy związane z równym statusem kobiet i mężczyzn, które oscylują pomiędzy „reklamą” kobiecości/męskości (czyli tym, co jest określane jako „demokracja masowa”) a próbami prowadzenia rzetelnego dyskursu publicznego. ${ }^{19}$

$\mathrm{Na}$ istniejące niebezpieczeństwo budowania ,jedynego słusznego" modelu rzeczywistości zwracał już uwagę J. Rawls, pisząc, że przestrzeń publiczna powinna być

18 B. Grabowska, Sfera publiczna - zbyteczna czy niezbędna w państwie liberalnym?, „Filo-Sofija” 2003 nr 1(3), s. 183-192.

19 W tym miejscu warto wspomnieć o inicjatywnie Fundacji Gender Center, która razem z Helsińską Fundacją Praw Człowieka wystąpiła z pierwszym w Polsce pozwem sądowym o seksistowską reklamę, http:// www.hfhr.org.pl/dyskryminacja/ (dostęp 06.10.2011). 
konstruowana w oparciu o wartości uniwersalne, takie jak: wolność, równość wobec prawa, sprawiedliwość, jakość życia, pluralizm i neutralność światopoglądowa. ${ }^{20}$

W Polsce na niebezpieczeństwo, jakie na życie kobiet wywiera ich fałszywy wizerunek kreowany przez media, zwracały uwagę m.in. J. Bator, A. Twardowska czy E. Olczyk. ${ }^{21}$ Dwie ostatnie pisały, że „wraz ze wzrostem aktywności organizacji kobiecych nasilą się kampanie o charakterze społecznym, które obejmą przemilczane dotąd problemy milionów polskich kobiet. Ważna jest odpowiedź na pytanie zasadnicze: Czy polskie kobiety chcą - i czy są do tego gotowe - zmiany swojej pozycji w patriarchalnym układzie sił; i czy gotowi są na to mężczyźni, którzy większą niezależność kobiet postrzegają jako osłabienie swojej dotychczasowej dominującej pozycji w rodzinie i w społeczeństwie? Doświadczenia społeczeństw rynkowych zdają się przemawiać za tym, że prognozy przewidujące zanikanie różnic społecznych związanych z płcią nie mają w polskiej rzeczywistości realnych podstaw". 22

Od czasu, kiedy napisano te słowa, upłynęło ponad dziesięć lat. Co w tym czasie zmieniło się w polskiej przestrzeni publicznej?

Generalnie pozycja kobiet we współczesnych mediach może być rozpatrywana na dwóch płaszczyznach: czynnej (aktywnej), na której pojawiają się one w rolach dziennikarzy, redaktorów itd., oraz pasywnej (biernej), na której stanowią jedynie fragment lub tło szerszego przekazu. Badania A. Twardowskiej i E. Olczyk pokazują, że w latach dziewięćdziesiątych w roli dziennikarek telewizyjnych występowały najczęściej kobiety w przedziale wiekowym od 25-40 lat. Ich styl ubierania, sposób zachowania były mocno związane z rodzajem prowadzonego programu. Zazwyczaj był to jednak strój określany jako tzw. kobiecy.

W programach o bardziej „luźnym” charakterze dominowały sukienki, jeansy, itp. Z kolei programy informacyjne „rządzą się surowszymi prawami: prowadzące noszą damskie garnitury bądź garsonki, jednak nie obowiązuje sztywna kolorystyka: biel, czerń, granat, popiel - zdarzają się jaskrawsze kolory" ${ }^{23}$

Jak zaznaczają obie autorki, kobiety uczestniczące w programach rozrywkowych pełnią w nich najczęściej drugorzędną rolę. Prowadzącymi kwizów, teleturniejów, przeglądów są na ogół mężczyźni, kobiety występują w nich w rolach asystentek. Widać w nich, jak stereotyp inteligentnego, kompetentnego i odpowiedzialnego mężczyzny jest przeciwstawiany stereotypowej kobiecie - istocie „z natury” czułej, gadatliwej i często roztrzepanej.

20 J. Rawls, Teoria sprawiedliwości, op.cit.

21 J. Bator, Wizerunek kobiety $w$ reklamie telewizyjnej, ISP, FSP, Warszawa, 08.1998; A. Twardowska,

E. Olczyk, Kobiety $w$ mediach, www.temida.free.ngo.pl/rapmedia.htm (dostęp 14.07.2011).

22 Ibidem.

23 Ibidem. 
Prezentowane kobiece wizerunki mają za zadanie „wzbogacenie” ogólnego przekazu, zgodnie z maksymą, iż to „kobiety łagodzą obyczaje”. Przykładami tego typu programów mogą być: „Jaka to melodia?”, gdzie kobiety występują np. w tle jako osoby śpiewające, czy „Taniec z gwiazdami”, gdzie kobieta rozmawia z gwiazdami w green roomie. Wyjątkiem jest program „You can dance”, gdzie osobą prowadzącą jest zawsze kobieta, ale warto zauważyć, że jej nie towarzyszy nigdy „asystent”.

$\mathrm{W}$ popularnych serialach i telenowelach można również dostrzec bogaty wachlarz występujących postaci kobiecych. Ich bohaterki trudnią się rozmaitymi zawodami, posiadają odmienny status ekonomiczny i społeczny, znajdują się w różnych sytuacjach życiowych, ale tym, co je wszystkie łączy, jest nieodmiennie nadrzędna wartość przypisywana rodzinie i posiadaniu dzieci. Kobiety samotne $\mathrm{z}$ wyboru, bezdzietne, pojawiają się stosunkowo rzadko i - co warto podkreślić - są to najczęściej bohaterki negatywne.

Kobiety są prezentowane $\mathrm{w}$ trakcie wykonywania prac domowych, rozmów z sąsiadkami, członkami rodziny. Można odnieść wrażenie, że bycie panią domu to jedyna droga prowadząca do szczęścia; ideał, do którego powinna dążyć każda kobieta. Wydawać się może, że niewiele uległo zmianie w tej kwestii od czasów, kiedy badania prowadziły przywoływane wcześniej A. Twardowska i E. Olczyk.

Zbliżona sytuacja występuje w radiu, w którym kobieta odczytuje bieżące wiadomości lub prowadzi audycje na tematy związane głównie ze zdrowiem, urodą, gotowaniem czy wychowywaniem dzieci.

Przeglądając prasę w poszukiwaniu artykułów napisanych przez kobiety, także można odczuć pewien niedosyt. Domeną kobiet okazują się bowiem być rubryki poświęcone zdrowiu oraz tematyce społecznej, gdyż - jak stwierdza R. Dziemba „[kobiety] są uważane za wrażliwsze i bardziej empatyczne”. ${ }^{24}$ Kobietę-dziennikarkę spotkać możemy najczęściej w redakcjach czasopism skierowanych do pań, programów telewizyjnych, poradników, magazynów dla nastolatek, natomiast periodyki poruszające tematykę fachową oraz ważne dla społeczeństwa informacje zazwyczaj stanowią domenę dziennikarzy-mężczyzn.

Interesujące uwagi na temat możliwości odniesienia sukcesu w świecie zdominowanym przez mężczyzn można znaleźć w tekście C. Michalskiego zamieszczonym w „Newsweeku”. 25 Stwierdza on, że ceną owego sukcesu jest „absolutne dziwactwo”. Analizując zjawisko opisywane przez siebie jako gagaizm, podaje przykłady Manueli Gretkowskiej i Jadwigi Staniszkis w Polsce (obok Lady Gagi i Madonny), aby pokazać,

24 R. Dziemba, „Słaba płeć” $w$ silnych mediach, w: Płeć $w$ życiu publicznym, red. M. Jeziński, M. Wincławska, B. Brodzińska, Wydawnictwo Naukowe UMK, Toruń 2009; więcej: http://www.eioba.pl/a/ 2r6q/kobieta-i-wizerunek-kobiecosci-w-mediach\#ixzzla7HtJg8K (dostęp 23.09.2011).

25 C. Michalski, Gagaistki, „Newsweek” 2011 nr 36, s. 118-119. 
że kobieta, aby się „przebić”, musi doprowadzić do tego, żeby mężczyźni zaczęli się jej bać. Inaczej będą je traktować jak maskotki, a w najlepszym razie - niewolnice. Mimo prowokacyjnego charakteru, tekst odwołuje się do potocznego przeświadczenia, że chcąc grać z mężczyznami, kobiety muszą najpierw nauczyć się ich reguł gry.

Generalnie jednak w wizerunkach kobiet prezentowanych w czasopismach i gazetach, podobnie jak w rozrywkowych programach telewizyjnych czy telenowelach, przeważa „kult kobiecości”. Jest ona jednak definiowana w specyficzny sposób. Kobiecość jest rozumiana jako „narcystyczna orientacja na samą siebie - na swój wygląd zewnętrzny (dążenie do bycia coraz piękniejszą), na sukces zawodowy i osobisty, ale rozumiany jako zdobycie i zatrzymanie przy sobie mężczyzny" ${ }^{26}$

Przeglądając tzw. prasę kolorową, można wręcz odnieść wrażenie, że prezentuje się w niej typ kobiety idealnej. Jest ona zależna od dokonywanych wyborów, które mają charakter głównie konsumpcyjny. ${ }^{27}$ Kobieta idealna w każdej sytuacji zachowuje się w niezwykły sposób, a jej głównym celem wydaje się być zdobycie i utrzymanie przy sobie mężczyzny, równie idealnego jak ona sama.

Obserwując, jak zmienia się sytuacja kobiet i mężczyzn na przestrzeni ostatnich lat, można zasadnie stwierdzić, że tylko naprawdę silne i ambitne jednostki będą $\mathrm{w}$ stanie skutecznie przeciwstawić się istniejącym stereotypom. ${ }^{28}$

Zamieszczone powyżej uwagi wydają się potwierdzać badania przeprowadzone na zlecenie Kongresu Kobiet. Pokazują one, że kobiety stanowią jedynie 14,6\% osób zapraszanych do programów publicystycznych. Większość stanowią mężczyźni. I co ciekawe, to mężczyźni prowadzący programy chętniej zapraszają do nich kobiety, niż dzieje się odwrotnie. ${ }^{29}$ Uzyskane wyniki były rezultatem badań prowadzonych przez pięć tygodni przez wynajętych przez Kongres studentów, którzy oglądali wybrane programy publicystyczne w największych telewizjach i rozgłośniach radiowych.

Okazało się, że na 885 gości zaproszonych do programów publicystycznych w telewizji publicznej i radiu, a także w TVN 24, Radiu ZET, RMF FM i TOK FM, kobiety stanowiły zaledwie 129 osób. Oznacza to, że na 6 mężczyzn przypadała 1 kobieta. I jak podkreślają autorzy badania, polskie kobiety nadal nie uczestniczą w kształtowaniu opinii publicznej, która stanowi przecież podstawę demokracji.

26 C.M. Renzetti, D.J. Curran, Kobiety, mężczyźni i społeczeństwo, Wydawnictwo Naukowe PWN, Warszawa 2005.

27 R. Dziemba, op.cit., s. 74.

${ }_{28}$ Kobieta $\mathrm{i}$ wizerunek kobiecości w mediach, http://www.eioba.pl/a/2r6q/kobieta-i-wizerunek-kobiecosciw-mediach (dostęp 23.09.2011).

29 Szowinizm w programach publicystycznych: badania, http://www.polskatimes.pl/dodatki/rozmaitosci/ 406717,szowinizm-w-programach-publicystycznych-badan (dostęp 7.10.2011). 
Swoistą postacią - ikoną najczęściej przywoływaną dla zaznaczenia faktu, że jednak istnieją kobiety, którym udało się odnieść sukces, jest Monika Olejnik, będąca rodzajem „wzorca” pokazującego innym, kim mogłyby się stać, gdyby im się „udało”."30

W tym miejscu trzeba mocno podkreślić, że to od współdziałania kobiet i mężczyzn, zarówno w przestrzeni prywatnej, jak i publicznej, będą zależały czas i kierunek dalszych zmian. I czy przybiorą one bardziej trwały charakter.

W dalszym ciągu jednak aktualne pozostaje pytanie, czy same kobiety będą $\mathrm{z}$ nich zadowolone.

Dotychczasowe obserwacje pokazują, że kobiety w polskich mediach coraz silniej zaznaczają swoją obecność. Rośnie liczebność dziennikarek, prezenterek, redaktorek, zarówno w radiu, jak i w telewizji. Niemniej jednak borykają się one ciągle $\mathrm{z}$ wieloma utrudnieniami i barierami na drodze do awansu. W porównaniu z mężczyznami muszą włożyć dużo więcej siły i zaangażowania, aby pokazać, ile naprawdę są warte. A istniejące stereotypy pozwalają na traktowanie ich samych i wykonywanej przez nie pracy w sposób często instrumentalny.

Obserwując tempo, w jakim zmienia się sytuacja, można rzeczywiście odnieść wrażenie, że to najsilniejsze i najbardziej ambitne $\mathrm{z}$ nich będą $\mathrm{w}$ stanie przebić się w realiach polskiej rzeczywistości. Czy to oznacza, że innym pozostaje jedynie bierne kibicowanie? Problem wydaje się być złożony. Przywoływana wcześniej H. Arendt zwracała uwagę, że w naszej cywilizacji doszło do zerwania dotychczasowych powiązań, jakie istniały pomiędzy pracą, wytwarzaniem i działaniem. Współcześnie dominuje wytwarzanie i towarzysząca mu osobowość. Są to zdolności do tworzenia i posiadania przedmiotów. Ludzie wykształceni, zamożni, bardziej autonomiczni potrafią lepiej radzić sobie w tej nowej sytuacji. Pozostali popadają w konformizm, który skłania do przedmiotowego traktowania nie tylko innych, ale i samych siebie, poddawania się różnym autorytetom i formom przymusu. ${ }^{31}$

Byłby to jeden wątek wart dalszych rozważań. Drugi, na który zwróciła uwagę R. Siemieńska, to ogromne zróżnicowanie sytuacji kobiet związane ze zmianą roli współczesnego państwa. ${ }^{32}$ Pisze ona: „[... ] po okresie poszerzania sfery publicznej

30 Dla przykładu: po wpisaniu w wyszukiwarkę Google nazwiska Monika Olejnik pojawiło się 634 tys. wyników, Kamil Durczok - 371 tys., Tomasz Lis - 796 tys., a Andrzej Morozowski - 85,9 tys. (dostęp 18.07.2011).

31 Podaję za: W. Morawski, Konfiguracje globalne. Struktury, agencje, instytucje, Wydawnictwo Naukowe PWN, Warszawa 2010, s. 92.

32 R. Siemieńska, Kontrakt płci. Między sfera prywatna a publiczną, w: Gender w społeczeństwie polskim, red. K. Slany, J. Struzik, K. Wojnicka, Wydawnictwo Nomos, Kraków 2011. 
polegającego (zwłaszcza w drugiej połowie XX w.) na przejmowaniu przez państwo odpowiedzialności za rozwiązywanie problemów, które jeszcze w epoce przemysłowej były głównie w gestii poszczególnych rodzin i jednostek (opieka nad dziećmi, ludźmi starymi i niedołężnymi), w ostatnich latach stają się sferą "bezpańską", niczyją, za którą ktoś musi odpowiadać”. ${ }^{33}$ Pojawia się pytanie, kto będzie za to odpowiedzialny i jakim kosztem to się odbywa. Warto zatem także przyjrzeć się i ocenić racjonalność oraz efektywność istniejącego wsparcia instytucjonalnego i nieinstytucjonalnych form działania; na ile i w jaki sposób wspierają one aktywność kobiet zarówno w sferze publicznej, jak i prywatnej.

Jak pisze A. Titkow, jedynym niekwestionowanym desygnatem sfery prywatnej pozostaje do tej pory nieodpłatna praca kobiet $\mathrm{z}$ wszystkimi jej konsekwencjami ${ }^{34}$. Zapomina się jednak przy tym, że decyzje, które dotyczą rodziny jako jej istotnego elementu zapadają w sferze publicznej. Obejmują między innymi kwestie praw kobiet do aborcji, dostępu do środków antykoncepcyjnych i możliwości ich refundacji czy też zakresu obecności kościoła katolickiego w naszym życiu codziennym. Wszystkie mają wpływ na sferę prywatną, ale są podejmowane poza nią.

Rysunek 5. Postrzeganie działalności instytucji społecznych na rzecz godnego przedstawiania kobiety $w$ reklamie $(w \%)$

Czy uważasz, że feministki i działacze społeczni tropiący seksizm w reklamach wykazują się brakiem poczucia humoru?
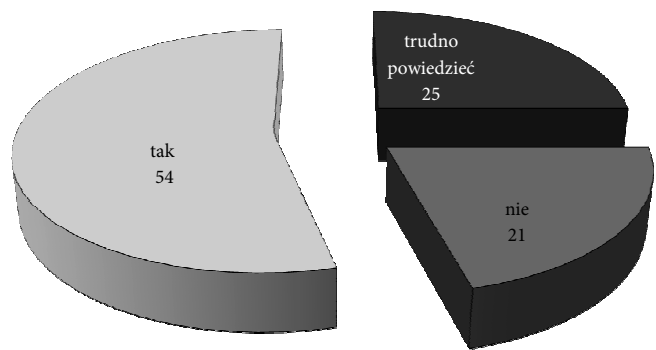

a Badanie wykonane przez Gemius dla „Newsweeka” na próbie 800 internautów.

Źródło: Seksizm $w$ reklamie. Wolne żarty, http://spoleczenstwo.newsweek.pl/seksizmw-reklamie-wolne-zarty,59 606,1,1.html (dostęp 07.10.2011).

Ciało staje się niezwykle istotnym elementem tożsamości kobiecej, na tyle silnym, iż „decyduje” nie tylko o tym, że czujemy się atrakcyjne fizycznie, ale wiążemy z nim możliwość osiągania sukcesu także w sferze zawodowej.

33 Ibidem, s. 197

${ }_{34}$ A. Titkow, Tożsamość polskich kobiet. Ciagłość, zmiana, konteksty, Wydawnictwo IFiS PAN, Warszawa 2007, s. 224. 
Konieczne wydaje się zatem stałe monitorowanie zachodzących zmian chociażby $\mathrm{w}$ tym celu, aby tzw. kwestie kobiece nie uległy marginalizacji i nie były traktowane jako mniej istotne z punktu widzenia rozwoju społecznego. Choć we wspomnianych w opracowaniu deklaracjach i dokumentach międzynarodowych, zarówno ONZ, Unii Europejskiej, jak i polskich, podkreśla się ważność ról społecznych pełnionych przez kobiety w rozwoju zrównoważonym, to codzienna praktyka pokazuje mniej optymistyczny obraz.

Warto zatem śledzić zmiany i odpowiednio szybko reagować na wszelkie próby ingerowania $\mathrm{w}$ już zdobyte prawa. Leży to bowiem zarówno $\mathrm{w}$ interesie samych kobiet, jak i mężczyzn.

\section{Woman in public sphere}

Recent years have brought far reaching changes in the Polish public sphere and woman have played their part in it. It is therefore important to ask about their motivation for participation in public affairs, describe their preferred strategies and think about future, that is ask the question about durability of the chosen models. Public sphere today is growing more and more diverse which makes the task of defining it more difficult than ever. We are still looking for answers to questions such as what is the public sphere? What categories can be used to mark boundaries of public sphere? Who and what influences public sphere? What are the subjects operating in public sphere and what are the limits of their power? J. Habermas, J.S. Mill, J. Rowls, A. Giddens and H. Arendt have tried to answer all those questions and many more. Their thoughts were my inspiration.

\section{Les femmes dans l'espace public}

Ces dernières années, de profonds changements ont été observés dans l'espace public polonais, dans lequel les femmes ont joué un rôle significatif. Il est important de se poser la question concernant les motifs de leur participation à des actions publiques, de montrer les stratégies utilisées et de réfléchir sur l'avenir et la viabilité de certains modèles. Aujourd'hui, l'espace public est de plus en plus diversifié, ce qui rend difficile de le definir. Il y a toujours des questions sans réponse: quest-ce que l' espace public, quelles sont les catégories qui pourraient aider à designer cet espace?, qui et quoi l'influence?, qui sont les acteurs publics et quelle est leur puissance? Les tentatives visant à répondre à ces questions peuvent être trouvées dans les travaux de J. Habermas, J.S. Mill, J. Rowls, A. Giddens et H. Arendt, qui étaient la source d'inspiration pour cette analyse. 